TITLE:

\title{
17. The Aggregation of Oriented Anisotropic Particles
}

$\operatorname{AUTHOR}(\mathrm{S})$ :

Miyazima, S.; Meakin, P.; Family, F.

\section{CITATION:}

Miyazima, S.... [et al]. 17. The Aggregation of Oriented Anisotropic Particles. 物性研究 1987, 49(1): 49-50

ISSUE DATE:

1987-10-20

URL:

http://hdl.handle.net/2433/92848

RIGHT: 
「パターン形成，その運動と統計」

ぎない。我々はこのペンローズ格子上にイジングスピンを配置して，そのスピン統計を論ずる ことにより，臨界指数等に準結晶の特徵を見出そうと試みた。方法はとり敢えず Monte Carlo 法により調べることにした。ペンローズ格子は非周期系であるため，うまく周期境界条件を加 えることが出来ないので，開放系のまま計算を行った。このため収束が悪く，さらに bulkの の性質（表面効果を取り除く）を得るための処理を加えた。格子数注 $1000 \sim 8000$ sitesの格子 を準備し，2万( モンテカルロ）ステップ〜 10 万ステップの計算をし，磁化，帯磁率などの 計算值を格子数または格子数の 2 乗を横軸としてプロットし，格子数の無限へと外挿した曲線 の傾きを求め bulk 值とした。

この結果, 臨界温度は $2.39 \mathrm{~J} / k \pm 0.02$ で正方格子の $2.37 \mathrm{~J} / k$ と比べやや大きい。ペン ローズ格子の平均配位数は 4 で正方格子と同じである。平均場近似では，両格子の臨界温度は 一致するが，正確には一致せず，この様な例は他のいくつかの乱れた采でも見出されている （庄司）。臨界指数については $\alpha=0.05 \pm 0.02, \beta=0.165 \pm 0.02, \gamma=1.7 \pm 0.4$ が得ら れた。 おり，ペンローズ格子上のイジング系は正方格子のイジング系と同じ universality class に属す ると言えそうである。

発表の後の宮下精二さんの議論に感謝致します。

17. The Aggregation of oriented Anisotropic Particles

\author{
S. Miyazima*, P. Meakin ${ }^{\circledR}$ and F. Family ${ }^{8}$ \\ *Department of Engineering Physics, \\ Chubu University, Kasugai, $\Lambda$ ichi 487, Japan \\ (Central Hesearch and Development Department, \\ Experimental Station, E.I.duPont de Numours and \\ Company, Inc. Wilmington, DE 19898
Department of Physics, Emory University, \\ Atlanta, GA 30322
}

The formation of cluster by the aggregation of small objects and by growth processes is a subject of considerable inlerest and of practical importance in physics, chemistry, biology, medicine, and engineering. In practice there are a lol of aggregation phenomena such as particles with induced dipole momenls in an external field, magnetic particles in an exlernal finld and polymerization in an ordered liquid crystal. 
研究会報告

Agglegation in ferrofluid is a particularly interesting examplo with condiderable scientific and practical importance. In this paper the limited aggregation of oriented anisotropic particies is investigated using computer simulations. Figure 1 below shows patterns formed linear rods in the $512 \times$ 512 square lattice. Initially 8000 particles are disti ibuled and the average cluster size is 20.19 and diffusion constant is assumed to be proportional to $\mathrm{s}^{-1}$. Figures 2 (a) and $2(\mathrm{~b})$ blow show patterns formed linear rods in 3-dimensional cubic laltice $(128$, where 10,000 partcles and distribuled initially and average cluster size is 40 . Figures 2 (top liv) are interscoted by a plane including the external field and ligs. 2 bottom right and left are a projection onto and an interscction by a plane respectively that is perpendicular to the external field. The aggregation process is well described by the cluster-size distribution function $N_{5}(t)$, which is the number of clusters of size $s$ at time $t$. By the dynamicl scaling theory the time dependent cluster-size distribution can be represented by the scaling form $N_{f}(t)=s^{-2} f(s / S(t))$ where $S(t)$ is the mean cluster size. St high particle densities a crossover from two (or threes dimensional behavior to that that is characteristic of a one dimensional system is found.

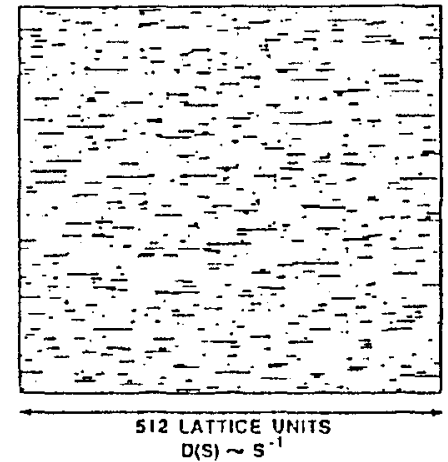

FIE. 1

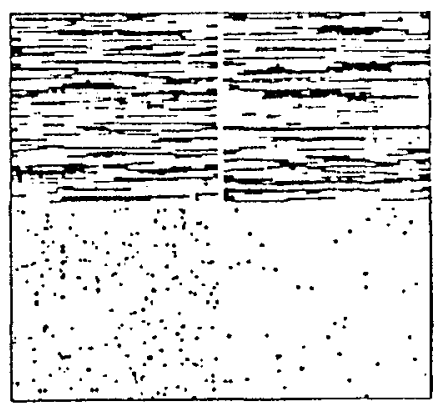

228 LATICE UAITS $12 B$ LATTICE UNIIS

FIg $\cdot 2$

\section{8. 液晶の秩序化過程に於けるパターン形成}

名大・工 長屋智之, 折原宏, 石橋善弘

\section{§1.はじめに}

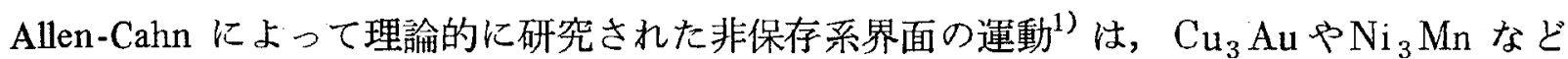
の秩序一無秩序転移をする合金を急冷する実験 ${ }^{2,3)}$ によりX線などを使って観測することがで きるが，折原らによって考案された $\mathrm{TN}$ セル (Twisted Nematic cell) を使った液晶の急椧実験 ${ }^{4}$ 